\title{
PRÓ LOGO
}

El mirador de la memoria

Algunos de los recuerdos más hermosos de mi niñez tienen que ver con los caminos que, junto a mi madre y mis hermanos, recorría para ir de Chimel, mi pequeña aldea natal, a Uspantán, la cabecera del municipio. Ahora pienso que las nueve horas de camino significaban mucho tiempo y mucho esfuerzo. Sin embargo, al paso de los años, sigo pensando que esos son los caminos más lindos que existen sobre la tierra. Una de las imágenes más bellas que conservo es la de una cumbre que, desde el pie del cerro, se veía muy alta, siempre poblada de nubes que descansaban sobre las copas de los árboles. Lo que me maravillaba cada vez que llegábamos a esa cumbre era la claridad y la inmensidad de la visión hacia atrás y hacia delante. Casi podíamos ver, a nuestra espalda, todos los cerros y los pequeños valles que habíamos recorrido y, frente a nosotros, los bosques interminables que debíamos atravesar.

Pienso ahora, cuatro décadas después de haber empezado a recorrer aquellos caminos, que la memoria es como esa cumbre maravillosa. Creo que la memoria es un mirador muy alto, desde el que podemos ver el camino ya recorrido e imaginar el largo trecho por transitar. Y, de verdad, esa imagen me ayuda a vivir con optimismo en medio de este mundo tan lleno de nubarrones y tempestades. La memoria no es solamente el recuerdo de la historia, es también la intuición del futuro.

Después del horror del genocidio cometido contra nuestro pueblo en Guatemala, la recuperación de la memoria-de la memoria histórica-se convierte en una de las claves de la supervivencia. Ese proceso es indispensable para poder sobrellevar y superar ese trauma apabullante para cualquier ser humano. La recuperación de la memoria es una medicina necesaria, indispensable, para poder $\mathrm{cu}$ rar las heridas lacerantes que nos dejaron esos espantosos crímenes contra la humanidad. Pero hay algo fundamental, la recuperación de la memoria histórica también implica la valoración de la lucha y los sacrificios por lograr una vida más digna; la valoración de los sueños que fueron arrancados violentamente del árbol que los genocidas quebraron y quemaron, pero al que no le pudieron matar la raíz.

Sin embargo esa memoria recuperada, como el mirador de la cumbre, nos debe permitir vislumbrar el futuro por construir. Para el pueblo Maya, y para los pueblos de Guatemala en general, resulta vital comprender que el futuro se edifica sobre la base de la memoria que nos haya permitido recuperar la identidad y la dignidad. La memoria nos posibilita entender que necesitamos conocer la verdad de lo ocurrido para buscar la justicia. Así se va integrando el camino que nos permite transitar de la memoria a la verdad y de la verdad a la justicia. Y ese es el único camino que puede conducir a Guatemala hacia la reconciliación y el perdón.

En esa perspectiva reside la mayor contribución de Monseñor Gerardi y de los cientos de mujeres y hombres que junto a él em- 
prendieron la tarea de ayudar a las víctimas y a los supervivientes del genocidio a recuperar la memoria, la identidad y la dignidad que pueden conducir a la justicia. Esa es la esencia del informe Guatemala: Nunca más que tanta luz le ha aportado a nuestro pueblo y al mundo sobre la magnitud del genocidio y otros crímenes contra la humanidad cometidos en nuestro país.

En ese amplio contexto debe ubicarse y entenderse una de las partes más importantes de la obra artística de nuestro querido y respetado Daniel Hernández-Salazar. A lo largo de los últimos años, Daniel ha enfocado su sensibilidad y su saber en el esfuerzo de captar la interrelación que existe entre la memoria y la dignidad de las víctimas y los sobrevivientes del genocidio. Registrar artísticamente esa realidad tan compleja y dolorosa-y hacerlo con tanta intensidad y belleza-solamente es posible por el talento y la enorme calidad humana de este fotógrafo excepcional.

Como síntesis plástica del informe Guatemala: Nunca más, Daniel nos ha legado ese ángel con alas de hueso, que es cuatro y es uno, al mismo tiempo que es testigo fiel y profeta que vuela desde las fosas comunes para decirle al mundo que la memoria es también semilla de futuro.

Rigoberta Menchú Tum

Premio Nóbel de la Paz 
SO THAT ALL SHALL KNOW

PARA QUE TODOS LO SEPAN 
